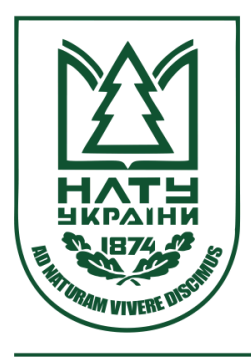

Науковий вісник НЛТУ України Scientific Bulletin of UNFU

https://nv.nltu.edu.ua

https://doi.org/10.36930/40300407

$@ \bowtie$ Correspondence author

Article received 17.09.2020 p.

Article accepted 07.07.2020 p.

O. M. Aboimova

UDC 634.51:282.485(477)

aboimovaaleksandra@gmail.com

О. М. Абоімова

Наиіональний ботанічний сад ім. М. М. Гришка НАН України, м. Київ, Україна

\title{
ОСОБЛИВОСТІ РЕПРОДУКТИВНОЇ ЗДАТНОСТІ ВИДІВ РОДУ JUGLANS L. У КОЛЕКЦІЙНИХ НАСАДЖЕННЯХ НАЦІОНАЛЬНОГО БОТАНІЧНОГО САДУ IMEНI М. М. ГРИШКА НАН УКРАЇНИ
}

\begin{abstract}
У 2016-2017 pp. визначено показники репродуктивної здатності видів роду Juglans L. Методи проведення досліджень: біолого-статистичні (візуальні спостереження та аналіз отриманих результатів), лабораторні (дослідження фертильності пилкових зерен). Виявлено, що частка фертильного пилку становила від 92,3 \% (J. regia L. f. fertilis Petz et Kirch.) до 70,4 \% (J. mandshurica Maxim.). Виявлено, що частка стерильного пилку найнижча у рослин $J$. regia L. f. fertilis Petz et Kirch. $(7,6 \%)$, вища - у рослин J. ailantifolia Carrière (35,1\%). 3'ясовано, що показники реальної насіннєвої продуктивності видів роду Juglans L. найвищі у J. regia L. f. fertilis Petz et Kirch. (10,7), а найнижчі - у J. microcarpa Berland. (0,5). Встановлено, що середнє значення потенційної репродуктивної здатності найвище у J. regia L. f. fertilis Petz et Kirch. - $(23,3)$, а найнижче - у J. microcarpa Berland. (1,6). Коефіцієнт продуктивності дослідних видів виявився найвищим у J. mandshurica Махіт. $(80,1)$, а найнижчим - у J. major (Torr.) A. Heller $(33,3)$. Найбільший врожай (6 балів) у дослідних рослин J. nigra L. зафіксовано у 2018 р., а найменший (2 бали) - у рослин J. microcarpa Berland. у 2017 р. Встановлено, що нежиттєздатного насіння дослідних видів в умовах інтродукції найбільше у J. regia L. f. fertilis Petz et Kirch. (3-2,7 \%), а найменше - у J. mandshurica Maxim. (0,6-0,7 \%). Виявлено, що стратифікація насіння видів роду Juglans L. в умовах інтродукції становить від 120 (60) ( $J$. regia L.f. fertilis Petz et Kirch.) до 145 днів (J. nigra L., J. cinerea L.). Найкраща схожість насіння для більшості дослідних видів Juglans L. спостерігалась під час осіннього посіві в грунт з оплоднями - до 92 \% (J. regia L.). Найгіршими виявились показники схожості насіння J. regia L. f. fertilis Petz et Kirch. (10\%). Дослідження показників репродуктивної здатності рослин роду Juglans L. показало, що отримані результати відрізняються між рослинами різних видів, проте види роду Juglans L. формують високу частку фертильного пилку - від 92,3 \% (J. regia L. f. fertilis Petz et Kirch.) до 70,4 \% (J. mandshurica Maxim.), щорічно плодоносять, формують виповнене схоже насіння, що говорить про адаптацію в умовах інтродукції.
\end{abstract}

Ключові слова: періодичність плодоношення; урожайність; фертильність пилкових зерен; життєздатність пилку, схожість насіння.

\section{Вступ}

Вивчення потенційних можливостей насіннєвої продуктивності і ступеня іiі реалізації дає змогу охарактеризувати репродуктивні можливості виду, здатність його до самовідтворення, а також оцінити успішність інтродукції. У природних популяціях, унаслідок дії на процеси репродукції різних чинників, постійно існує невідповідність між потенційною $\mathrm{i}$ реальною насіннєвою продуктивністю. На формування процесів запилення та розвитку плодів впливають температура i вологість повітря, негативна дія яких призводить до зниження врожаю [11]. Насінну продуктивність поділяють на: потенційну (кількість квіток у суцвітті) та фактичну (реальну) (кількість плодів, що дозріли і виповнені) $[13,18]$. Плодоношення - важливий критерій успіху інтродукції рослин, тому вважається підсумковим відображенням всієї життєдіяльності рослинних організмів $[8,10,12]$.

Показники виповненості та схожості насіння інтро- дуцентів вважають важливими показниками успішності інтродукції рослин [11]. Отже, завданням наших досліджень $\epsilon$ вивчення показників репродуктивної здатності рослини роду Juglans L., a саме: дослідження показників життєздатності пилкових зерен, визначення коефіцієнта продуктивності, вивчення показників урожайності, дослідження життєздатності насіння; визначення терміну, потрібного для проходження стратифікації насіння та вивчення показників схожісті насіння.

Об'єкт дослідження - особливості репродуктивної здатності представників роду Juglans L.

Предмет дослідження - методи і засоби встановлення особливостей репродуктивної здатності представників роду Juglans L. у колекційних насадженнях національного ботанічного саду імені М. М. Гришка НАН України, що дасть змогу визначити можливість інвазійного поширення видів роду Juglans L. в регіоні інтродукції.

Мета дослідження зводиться до аналізу особливостей репродуктивної здатності представників роду Jug-

\section{Інформація про автора:}

Абоімова Олександра Миколаївна, аспірант, пров. інженер, відділ акліматизації плодових рослин. Email: aboimovaaleksandra@gmail.com; https://orcid.org/0000-0002-3622-4669

Цитування за дсту: Абоімова О. М. Особливості репродуктивної здатності видів роду Juglans L. y колекційних насадженнях національного ботанічного саду імені М. М. Гришка НАН України. Науковий вісник НлТУ України. 2020, т. 30, № 4. С. 41-45.

Citation APA: Aboimova, O. M. (2020). Some peculiarities of reproductive ability of species of the genus Juglans L. in collection plantations of M. M. Gryshko National Botanic Garden of the NAS of Ukraine. Scientific Bulletin of UNFU, 30(4), 41-45. https://doi.org/10.36930/40300407 
lans L. у колекційних насадженнях національного ботанічного саду імені М. М. Гришка НАН України.

Для досягнення зазначеної мети потрібно виконати такі основні завдання дослідження: здійснити аналіз літературних джерел, викласти методику, основний матеріал та результати дослідження, проаналізувати результати дослідження та зробити відповідні висновки.

Наукова новизна отриманих результатів дослідження полягає у тому, що в умовах інтродукції вперше вивчено особливості репродуктивної здатності представників роду Juglans L., що має як теоретичне, так і практичне значення для відбору перспективних видів і форм.

Практична значущість результатів дослідження полягає у тому, що встановлені особливості репродуктивної здатності представників роду Juglans L. здійснено за загальноприйнятими методиками, а урожайність визначали за візуальною шкалою В. Г. Каппера. Життєздатність насіння визначали способом розпилювання за методикою В. І. Нєкрасова. Висів насіння у грунт здійснювали за рекомендаціями О. К. Дорошенка.

Аналіз останніх досліджсень $\boldsymbol{i}$ публікацій показав, що види роду Juglans L. цінуються лікарськими та їстівними властивостями $[6,17] .3$ іншого боку, відомо, що види роду Juglans L. схильні до міжвидової гібридизації та інвазійності $[1,2,4,16]$. Однак особливості репродуктивної здатності видів роду Juglans L. у Лісостепу України не досліджували. Тому наукова новизна полягає у вивченні репродуктивної здатності дослідних ви- дів, що є актуальним як з практичного боку, так і теоретичного для прогнозування можливих наслідків спонтанного їх поширення та відбору цінних селекційних форм.

Матеріали та методи дослідження. Визначення показників реальної і потенційної насіннєвої продуктивності видів роду Juglans L. проводили за "Методическими указаниями по семеноведению интродуцентов" [18] та I. В. Вайнагія [15]. Визначали такі показники: кількість квіток - потенційна репродуктивна здатність (ПРЗ) та плодів, що дозріли і виповнені - реальна репродуктивна здатність (РРЗ) на пагонах у трикратній повторності. На основі зібраних даних розраховували усереднене значення показників потенційної та реальної насіннєвої продуктивності - коефіцієнт продуктивності $\left(K_{n p}\right)$. Для оцінювання якості пилку аналізували кількісні показники фертильних і стерильних зерен за методикою 3. П. Паушевої [Pausheva, 1968]. Урожайність визначали за візуальною шкалою В. Г. Каппеpa [9]. Життєздатність насіння визначали способом розпилювання [12]. Висів насіння у грунт здійснювали за рекомендаціями О. К. Дорошенка [5].

\section{Результати дослідження та їх обговорення}

Усі дослідні рослини вступили в генеративну фазу розвитку; цвітіння і плодоношення відзначено щорічно. У 2016-2017 рр. визначали показники життєздатності пилку видів роду Juglans L. (таблиця).

Таблиця. Показники життєздатності пилку дослідних видів роду Juglans L.

\begin{tabular}{|c|c|c|c|c|c|c|c|c|c|c|}
\hline \multirow{5}{*}{ Вид, форма } & \multicolumn{10}{|c|}{ Кількість пилкових зерен } \\
\hline & \multicolumn{2}{|c|}{ Рік } & \multicolumn{4}{|c|}{ Рік } & \multicolumn{4}{|c|}{ Рік } \\
\hline & 2016 & 2017 & \multicolumn{2}{|c|}{2016} & \multicolumn{2}{|c|}{2017} & \multicolumn{2}{|c|}{2016} & \multicolumn{2}{|c|}{2017} \\
\hline & \multirow{2}{*}{\multicolumn{2}{|c|}{ Всього, шт. }} & \multicolumn{4}{|c|}{ фертильних } & \multicolumn{4}{|c|}{ стерильних } \\
\hline & & & шт. & $\%$ & шт. & $\%$ & шт. & $\%$ & шт. & $\%$ \\
\hline J. regia $\mathrm{L}$. & 217 & 225 & 190 & 87,5 & 180 & 80,0 & 27 & 12,5 & 45 & 20,0 \\
\hline J. regia L.f. fertilis Petz et Kirch. & 184 & 180 & 170 & 92,3 & 145 & 80,5 & 14 & 7,6 & 35 & 19,5 \\
\hline J. cinerea $\mathrm{L}$. & 210 & 220 & 185 & 88,1 & 195 & 88,6 & 25 & 11,9 & 25 & 11,4 \\
\hline J. nigra $\mathrm{L}$. & 160 & 180 & 145 & 90,6 & 130 & 72,2 & 15 & 9,4 & 50 & 27,8 \\
\hline J. major (Torr.) A. Heller & 196 & 200 & 181 & 92,4 & 150 & 75,0 & 15 & 7,6 & 50 & 25,0 \\
\hline J. microcarpa Berland. & 221 & 210 & 192 & 86,9 & 180 & 86,0 & 29 & 13,1 & 30 & 14,0 \\
\hline $\begin{array}{l}\text { J. ailantifolia Carrière var. cordi- } \\
\text { formis }\end{array}$ & 216 & 220 & 197 & 91,2 & 165 & 75,0 & 19 & 8,8 & 55 & 25,0 \\
\hline J. ailantifolia Carrière & 170 & 185 & 155 & 91,2 & 120 & 64,9 & 15 & 8,8 & 65 & 35,1 \\
\hline J. mandshurica Maxim. & 198 & 220 & 161 & 87,5 & 155 & 70,4 & 37 & 12,5 & 65 & 29,6 \\
\hline
\end{tabular}

Під час дослідження пилкових зерен виявлено високу частку фертильного пилку - від 92,3\% (J. regia L. $f$. fertilis Petz et Kirch.) до 70,4 \% (J. mandshurica Maxim.), що підтверджує літературні дані щодо можливості міжвидового і внутрішньовидового схрещування Burda, 2018. Частка стерильного пилку найнижча у рослин $J$. regia L. f. fertilis Petz et Kirch. - 7,6\%, вища - у pocлин J. ailantifolia Carrière (35,1\%).

За результатами дослідження репродуктивної здатності видів роду Juglans L., показники реальної насіннєвої продуктивності виявились найвищими у J. regia L. f. fertilis Petz et Kirch. (10,7), а найнижчими - у J. microcarpa Berland. $(0,5)$.

Середнє значення потенційної репродуктивної здатності виявилось найвищим у J. regia L. f. fertilis Petz et Kirch. - (23,3), а найнижчим - у J. microcarpa Berland. $(1,6)$. Результати дослідження РРЗ та ПРЗ видів роду Juglans L. відображено на рис. 1.

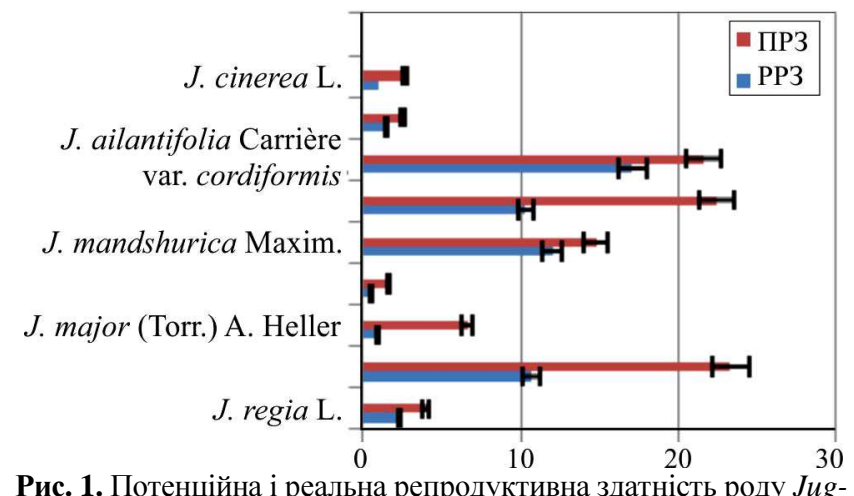

Рис. 1. Потенційна і реальна репродуктивна здатність роду Juglans L.

Коефіцієнт продуктивності $\left(K_{n p}\right)$ дослідних видів виявився найвищим у $J$. mandshurica Maxim., а найнижчим - у J. major (Torr.) A. Heller $(33,3)$ (рис. 2). 


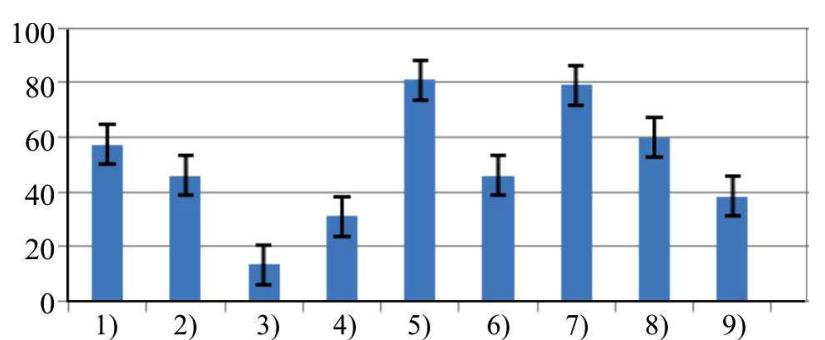

Рис. 2. Коефіцієнт репродуктивної здатності рослин роду Juglans $L$. Позначення: 1) J. regia $L$. 2) J. regia $L$. f. fertilis Petz et Kirch. 3) J. major (Torr.) A. Heller 4) J. microcarpa Berland. 5) J. mandshurica Maxim. 6) J. ailantifolia Carrière 7) J. ailantifolia Carrière var. cordiformis 8 ) J. nigra $L$. 9) J. cinerea $\mathrm{L}$.

Гришко-Богменко Б. К. у своїх дослідженнях видів poду Juglans L., здійснених понад 60 років тому в Національному ботанічному саду ім. М. М. Гришка, зазначав, що північноамериканські види Juglans L. плодоносять періодично [7].

За період досліджень, проведених у 2015-2018 pp., періодичності плодоношення не зафіксовано, урожай щорічний, навіть за несприятливих погодних умов. Так, пізньовесняний заморозок 2017 р. (30.05) припав на фазу цвітіння і зав'язування плодів, що призвело до загального зменшення врожайності усіх рослин (2-4 бали) порівняно 3 іншими роками досліджень (4-6 балів) за шкалою Каппера, коли пізньовесняних заморозків не було. Найбільший врожай (6 балів) у дослідних рослин $J$. nigra L. зафіксовано у 2018 р., а найменший (2 бали) - у рослин J. microcarpa Berland. у 2017 р. (рис. 3).

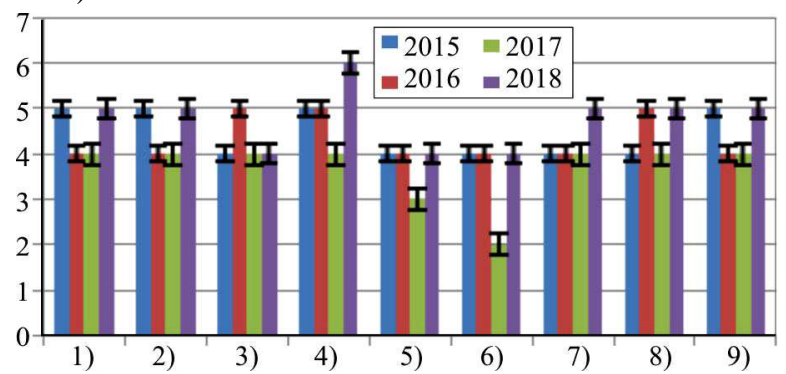

Рис. 3. Урожайність видів роду Juglans L. (2015-2018pp.). Позначення: 1) J. regia $L$. 2) J. regia $L$. f. fertilis Petz et Kirch. 3) J. cinerea L. 4) J. nigra L. 5) J. major (Torr.) A. Heller 6) J. microcarpa Berland. 7) J. ailantifolia Carrière var. cordiformis 8) J. ailantifolia Carrière 9) J. mandshurica Maxim.

Щодо життєздатності (рис. 4) насіння з'ясовано, що нежиттєздатного найбільше у J. regia L. f. fertilis Petz et Kirch. (2,7-3,0 \%), а найменше - у J. mandshurica Maxim. $(0,6-0,7 \%)$.

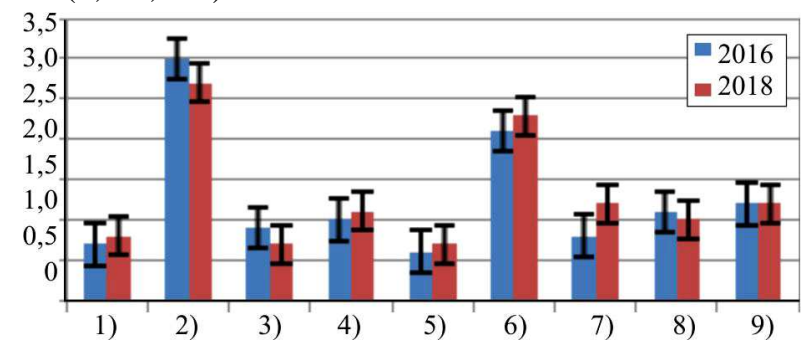

Рис. 4. Життєздатність насіння Juglans $L$. Позначення: 1) J. regia L. 2) J. regia L. f. fertilis Petz et Kirch. 3) J. major (Torr.) A. Heller 4) J. microcarpa Berland. 5) J. mandshurica Maxim. 6) J. ailantifolia Carrière 7) J. ailantifolia Carrière var. cordiformis 8) J. nigra L. 9) J. cinerea $\mathrm{L}$.

З'ясовано, що стратифікація насіяння дослідних видів становить: J. ailantifolia Carrière var. cordiformis, J. ailantifolia Carrière $J$. regia L., J. mandshurica Maxim. 120 днів; у J. major (Torr.) A. Heller, J. microcarpa Berland. - 130 днів; J. nigra L., J. cinerea L. - 145 днів. Насіння J. regia L. $f$. fertilis Petz et Kirch. потребує стратифікації від 60 до 120 днів.

Під час дослідження показників схожості насіння виявлено, що найкраща схожість насіння для більшості дослідних видів Juglans L. характерна для осіннього посіву в грунт з оплоднями (рис. 5), яка становила до $92 \%$ (J. regia L.). Найгіршими виявились показники схожості J. regia L.f. fertilis Petz et Kirch. (10\%).

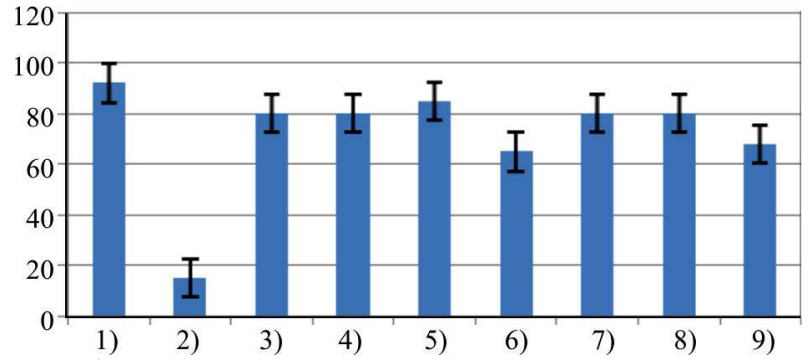

Рис. 5. Грунтова схожість насіння Juglans $L$. під час осінньої сівби в грунт (з оплоднями). Позначення: 1) J. regia $L$. 2) J. regia L. f. fertilis Petz et Kirch. 3) J. major (Torr.) A. Heller 4) J. microcarpa Berland. 5) J. mandshurica Maxim. 6) J. ailantifolia Carrière 7) J. ailantifolia Carrière var. cordiformis 8) J. nigra L. 9) J. cinerea L.

Насіння, що замочували на 3 доби та яке проходило стратифікацію у вологій тирсі без оплодня, зберігалося в неопалюваному приміщенні весь термін стратифікації, мало частку грунтової схожості від 20 \% (J. regia L. f. fertilis Petz et Kirch.) до $85 \%$ (J. mandshurica Maxim.) (рис. 6).

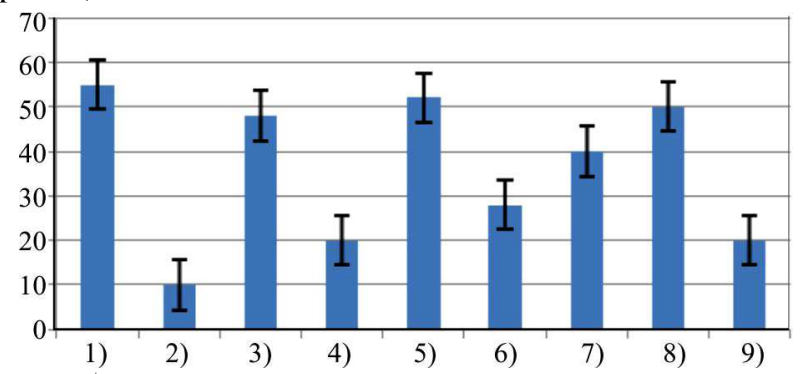

Рис. 6. Грунтова схожість насіння Juglans L. після стратифікації у сирій тирсі (без оплоднів). Позначення: 1) J. regia L. 2) J. regia L. f. fertilis Petz et Kirch. 3) J. major (Torr.) A. Heller 4) J. microcarpa Berland. 5) J. mandshurica Maxim. 6) J. ailantifolia Carrière 7) J. ailantifolia Carrière var. cordiformis 8) J. nigra L. 9) J. cinerea L.

Унаслідок стратифікації горіхів з оплоднями в сирій тирсі в неопалюваному приміщенні схожість становила: від $10 \%$ (J. regia L. f. fertilis Petz et Kirch.) до $55 \%$ (J. regia) (рис. 7).

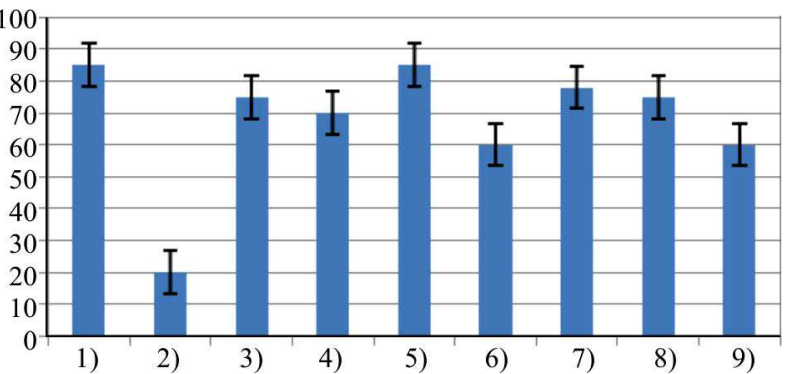

Рис. 7. Грунтова схожість насіння Juglans L. після стратифікації в сирій тирсі (з оплоднями). Позначення: 1) J. regia $L$. 2) J. regia L. f. fertilis Petz et Kirch. 3) J. major (Torr.) A. Heller 4) J. microcarpa Berland. 5) J. mandshurica Maxim. 6) J. ailantifolia Carrière 7) J. ailantifolia Carrière var. cordiformis 8) J. nigra L. 9) J. cinerea L. 
Після стратифікації насіння з висушеними оплоднями в сухій тирсі в неопалюваному приміщенні схожість становила: від $15 \%$ (J. nigra L.) до $50 \%$ (J. regia) (рис. 8) Перед посівом у грунт насіння замочували на три доби, воду міняли.

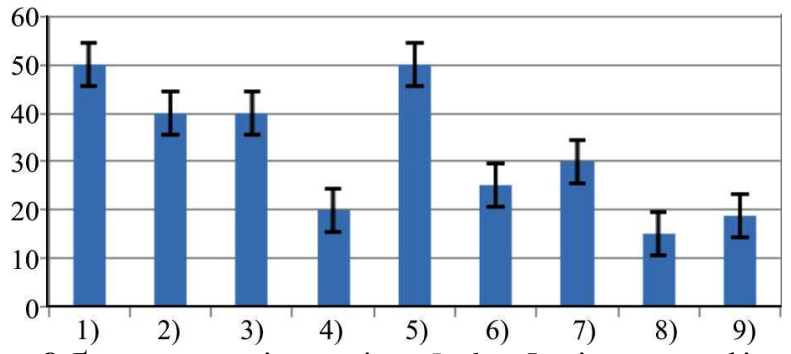

Рис. 8. Грунтова схожість насіння Juglans L. після стратифікації в сухій тирсі (з оплоднями). Позначення: 1) J. regia $L$. 2) J. regia L. f. fertilis Petz et Kirch. 3) J. major (Torr.) A. Heller 4) J. microcarpa Berland. 5) J. mandshurica Maxim. 6) J. ailantifolia Carrière 7) J. ailantifolia Carrière var. cordiformis 8) J. nigra L. 9) J. cinere L.

Отже, низька схожість $J$. regia L. $f$. fertilis Petz et Kirch., зафіксована під час посіву у грунт (10\%), пов'язана 3 коротким терміном стратифікації (12060 днів). Насіння після посіві у грунт восени проростає $(65 \%)$ і пошкоджується низькими температурами, тому його не рекомендують стратифікувати в оплодні зволоженим. Найкращий показник грунтової схожості J. regia L. f. fertilis Petz et Kirch. (40\%), порівняно з показниками інших варіантів стратифікації зафіксовано внаслідок зберігання в сухій тирсі, що можна пояснити коротким терміном стратифікації, який характерний для рослин Східноазійського ареалу походження [14]. Після стратифікації без зволоження насіння J. regia L. f. fertilis Petz et Kirch. переходить у фазу вимушеного спокою і не проростає.

\section{Висновки}

Під час дослідження життєздатності пилкових зерен видів роду Juglans L. частка фертильного пилку становила від 92,3\% (J. regia L. f. fertilis Petz et Kirch.) до $70,4 \%$ (J. mandshurica Maxim.). Частка стерильного пилку становила від 7,6\% (J. regia L. f. fertilis Petz et Kirch.), до $35,1 \%$ у рослин $J$. ailantifolia Carrière.

За період досліджень показники реальної насіннєвої продуктивності виявились найвищими у J. regia L. $f$. fertilis Petz et Kirch. (10,7), а найнижчими - у J. microcarpa Berland. $(0,5)$. Середнє значення потенційної репродуктивної здатності виявилось найвищим у J. regia L. f. fertilis Petz et Kirch. - $(23,3)$, а найнижчим - у J. microcarpa Berland. $(1,6)$. Коефіцієнт продуктивності дослідних видів виявився найвищим у $J$. mandshurica Maxim. $(80,1)$, а найнижчим - у J. major (Torr.) A. Heller $(33,3)$.

За період спостережень періодичності плодоношення видів роду Juglans L. встановлено, що всі рослини плодоносили щорічно. Урожайність усіх рослин Juglans L. за період досліджень коливалась від 2 (J. microcarpa Berland.) до 6 (J. nigra L.) балів.

Вивчення життєздатності насіння показало, що нежиттєздатного виявилось найбільше у рослин J. regia L. f. fertilis Petz et Kirch. (2,7-3,0\%), а найменше у $J$. mandshurica Maxim. (0,6-0,7 \%).

Стратифікація насіння видів роду Juglans L. в умовах інтродукції становить від 120 (60) (J. regia L. f. fertilis Petz et Kirch.) до 145 днів (J. nigra L., J. cinerea L.). 3'ясовано, що найкраща схожість насіння для більшості дослідних видів Juglans L. характерна для осіннього посіву в грунт з оплоднями, яка становила до $92 \%$ (J. regia). Найгіршими виявились показники грунтової схожості насіння J. regia L. f. fertilis Petz et Kirch., яке проходило стратифікацію у грунті- $10 \%$, шо пов'язано 3 коротким терміном стратифікації- 60120 днів. Загалом, аналізуючи отримані дані досліджень репродуктивної здатності видів роду Juglans L., виявлено низку відмінностей, проте рослини плодоносять щорічно і формують виповнене насіння для подальшої репродукції в умовах Лісостепу України. Підтвердились літературні дані про можливість інвазійного поширення видів роду Juglans L. в регіоні інтродукції.

\section{References}

1. Bagrikova, N. A. (2012). The importance of introducers in the adventization of regional flora on the example of the Crimea. Dendrology, floriculture and garden and park construction. Mater. international. conference dedicated to the 200th anniversary of the Nikitsky Botanical Garden. Yalta, June 5-8, 2012. Yalta, 7.

2. Bagrikova, N. A. (2013). Structural analysis of the adventitious fraction of the flora of the Crimean Peninsula (Ukraine). Ukr. botan. Journal, 70(4), 489-507.

3. Burda, R. I. (2015). Alien species of protective flora of the foreststeppe of Ukraine: monograph. NAS of Ukraine, Gos. Institution Institute of Evolutionary Ecology of the National Academy of Sciences of Ukraine, Kyiv: Naukova Dumka, 113 p.

4. Burda, R. I. (2018). Spontaneous settlement of Juglans L. species in the forests and parks of Kiev. Ros. Journal. biol. invasions, 1, 2-17.

5. Doroshenko, A. K.(1988). Germination and growth features of the species of the genus Walnut introduced in the CRBS of the Academy of Sciences of the USSR depending on the timing of sowing seeds and methods of their preparation. Introduction and acclimatization of plants, 69, 25-28.

6. Gorokhova, S. V. (2009). Useful properties of representatives of the genus Juglans L. Bulletin of the Issykkul University. Karakol. 23, 99-105.

7. Grishko-Bogmenko, B. K. (1969). Biological features of species of the genus Juglans L. in the Forest-Steppe of Ukraine: auto-ref. dis. on scientist, Ph.D. agricultural sciences: special 03.00.05 Botany Grishko-Bogmenko Boris Konstantinovich. Ukr. a-s. Academy. Kiev, 20 p.

8. Kalinichenko, A. A. (1978). Estimation of adaptability and expediency of introduction of woody plants. Bull. GBS AN SSSR, (108), 3-8.

9. Kapper, V. G. (1930). On the organization of annual systematic observations on the fruiting of tree species. Pr. on forest experimental work, 8, 103-139.

10. Kohno, N. A. (1980). To the method of evaluating the success of the introduction of deciduous woody plants. Theories and methods of plant introduction and green building. Proceedings of the Republican Conference, pp. 52-54. Kiev: Nauk. dumka.

11. Lapin, P. I.\& Sidneva, S. V. (1973). Estimation of prospects of introduction of woody plants according to visual observations. Experience of introduction of woody plants, pp. 7-67.

12. Nekrasov, V. I. (1973). Fundamentals of seed production of woody plants during introduction. Moscow: Nauka, $279 \mathrm{p}$.

13. Nekrasov, V. I. (1980). Actual questions of development of the theory of acclimatization of plants, $102 \mathrm{p}$.

14. Nikolaeva, M. G. (1977). Some results of the study of seed dormancy. Bot. Journal, 62(9), 1350-1368.

15. Pausheva, Z. P. (1968). Fertility and viability of pollen. Workshop on plant cytology. Moscow: Nauka, 213-217.

16. Rulek P., Lambdon, P. W., Arianoutsou, M., Kyhn, I., Pino, J., \& Winter, M. (Eds.). (2009). DAISIE. Handbook of Alien Species in 
Europe. Alien Vascular Plants of Europe. Springer, 2009. XXXVIII, $400 \mathrm{p}$.

17. Shchepotyev, F. L., Pavlenko, F. A., \& Richter, A. L. (1975). Nuts. Kyiv: Urozhay, 168 p.
18. Sidneva, S. V. (1980). Methodical instructions on seed science of introducers. Moscow: Nauka, $64 \mathrm{p}$.

19. Vainagy, I. V. (1974). On the methodology for studying the seed productivity of plants. Bot. Journal, 59(6), 826-831.

O. M. Aboimova

M. M. Gryshko National Botanical Garden, NAS Ukraine, Kyiv, Ukraine

\section{SOME PECULIARITIES OF REPRODUCTIVE ABILITY OF SPECIES OF THE GENUS JUGLANS L. IN COLLECTION PLANTATIONS OF M. M. GRYSHKO NATIONAL BOTANIC GARDEN OF THE NAS OF UKRAINE}

The determination of reproductive capacity of species of the genus Juglans L. was performed in the period of 2016-2017. Research methods that were applied were as folllows: biological and statistical (visual observations and analysis of the results); laboratory (pollen fertility studies). In the course of research we have found that the percentage of fertile pollen ranged from $92.3 \%$ (J. regia L. f. fertilis Petz et Kirch.) to $70.4 \%$ (J. mandshurica Maxim.). The percentage of sterile pollen is revealed to be the lowest in plants of J. regia L. f. fertilis Petz et Kirch. - $7.6 \%$, higher in plants J. ailantifolia Carrière (35.1\%). The indicators of real seed productivity of species of the genus Juglans L. were the highest in J. regia L. f. fertilis Petz et Kirch. (10.7), and the lowest in J. microcarpa Berland. (0.5). The average value of potential reproductive capacity was the highest in J. regia L. f. fertilis Petz et Kirch. - (23.3), and the lowest in $J$. microcarpa Berland. (1.6). The productivity coefficient of the experimental species was the highest in $J$. mandshurica Maxim. (80.1) and the lowest in J. major (Torr.) A. Heller (33.3). The research has also identified that the highest yield (6 points) in experimental plants of $J$. nigra L. was recorded in 2018, and the lowest (2 points) in plants of J. microcarpa Berland. in 2017. Non-viable seeds of experimental species in terms of introduction are the most abundant in J. regia L. f. fertilis Petz et Kirch. (3-2.7 \%), and the least in J. mandshurica Maxim. (0.6-0.7\%). The stratification of seeds of species of the genus Juglans L. in terms of introduction ranges from 120 (60) (J. regia L.f. fertilis Petz et Kirch.) to 145 days (J. nigra L., J. cinerea L.). The best seed germination for most of the experimental species of Juglans L. was observed during autumn sowing in the soil with fertilizers, which amounted to $92 \%$ (J. regia). Seed germination rates of J. regia f. fertillis was $10 \%$. A study of the reproductive capacity of plants of the genus Juglans L. showed that the results differ between plants of different species, but species of the genus Juglans L. form a high percentage of fertile pollen, i.e. from $92.3 \%$ (J. regia L. f. fertilis Petz et Kirch.) to $70.4 \%$ J. mandshurica Maxim.), fruiting annually, form a complete similar seed, which indicates adaptation to the conditions of introduction.

Keywords: periodicity of fruiting; yield; fertility of pollen grains; viability of pollen. 